\title{
Modern Foreign Experience of Antimonopoly Regulation of Digital Companies and Internet Platforms
}

\author{
Valery Istomin* \\ Institute of Philosophy and Law of the Ural Branch of the Russian Academy of Sciences, Ekaterinburg, Russia \\ Ural State University of Economics, Ekaterinburg, Russia \\ ${ }^{*}$ Corresponding author.Email: ValeryVS@rambler.ru
}

\begin{abstract}
The paper considers peculiarities of competition in modern digital markets, characterizes digital platforms as important elements of currently developing economic and social ties, and also examines the antimonopoly regulation of the activities of large digital companies in the United States and the European Union. Based on the practice of antimonopoly regulation that has developed in economically developed countries, the author concludes that digital companies are quite active in influencing markets in order to gain unjustified competitive advantages; the company's market power increasingly determined by such new features as network effects, large databases, and intellectual property objects. This requires antimonopoly authorities to improve continuously methods of countering digital monopolies, including coordinating efforts at the international level. The author also makes some suggestions on the development of antimonopoly regulation.
\end{abstract}

Keywords: market, antimonopoly regulation, digital Internet platform, digital company, restriction of competition.

\section{INTRODUCTION}

One of the most important trends of modern economy is its digitalization, development of new digital forms of economic relations. The latter are formed through the introduction of various information systems, the use of software products and digital technologies. Another trend in the global economy is ongoing globalization and internationalization of economic ties, the examples of which are offers to consumers around the world for products and services made by companies, their entering the markets of various countries. In this regard, traditional analog material-intensive markets and sectors of the economy are changing, which results in a radical transformation of the foundations of human life as a whole [1]. The digital economy is characterized by the rapid emergence of new high-tech markets and services covering a large number of participants. At the same time, there is competition in such markets, and aggregator companies that ensure functioning of digital platforms often seek to monopolize such markets or implement other restrictive business practices there. In this regard, modern states are trying to determine what their further actions should be in the field of antimonopoly regulation of digital public relations in order to prevent threats to normal functioning of the market mechanism [2]. Also, one of serious problems of digitalization of markets is protection of the rights of consumers of goods and services bought on electronic platforms. It is noted in the scientific literature that at present there is a need to protect the consumer not only from unscrupulous actions of the seller, but also from unscrupulous actions of the aggregator of the information about goods, works and services, i.e. the owner of the site where the buyer purchases goods, orders work or service [3]. Finally, methods of digital market research and criteria for determining the dominant position of economic entities on them, including the impact of the company's accumulation of a large amount of user data on its market position, require serious evaluation and improvement. All this makes it necessary to work out antimonopoly legislation and improve the practice of its application, as well as coordinate the efforts of various states and international organizations in the direction of developing common approaches to analyzing the market 
behavior of modern digital companies, do research of progressive foreign law enforcement experience.

\section{METHODS OF RESEARCH AND LEGAL ASSESSMENT OF FUNCTIONING OF INTERNET PLATFORMS AND ACTIVITIES OF DIGITAL COMPANIES IN MODERN MARKETS}

Currently, in the markets of many states there are actively functioning the so-called digital technological online platforms, which are electronic means of ensuring interaction between sellers and buyers of various products and services. These information platforms operate in various sectors of economy and specialize in different types of activities. For example, there are widely known digital platforms, operating as trading platforms (Amazon, AliExpress), social networks (WhatsApp, Facebook, Snapchat), search and information services (Google, Yandex), payment and account systems (PayPal). In addition, in recent years, many large companies engaged in developing software and operating systems (Apple, Google-Alphabet, etc.) have begun to create their own digital online platforms that trade or provide services, such companies often being the copyright holders of various results of intellectual activities in the high-tech field. This complicates to a certain extent the antimonopoly assessment of the activities of companies using their own developments in functioning of the platforms. As the European Organization for Economic Cooperation and Development (OECD) notes high revenues and impressive growth in the value of companies providing Internet platforms can be explained, among other things, by the fact that many of these platforms have mainly digital products and can "scale without mass." Compared to traditional firms which make products at fixed and marginal costs, digital companies tend to have a relatively small number of tangible assets and employees, as well as low marginal costs. In addition, unlike the above firms, the value of platforms depends not only on sales and profitability, but may significantly depend on their assessment by platform users (individuals or firms) and the data received from these users [4]. The European Commission defines digital (online) platforms as software tools offering bilateral or even multilateral markets where suppliers and users of content, goods and services can meet [5]. In legal science, a digital platform is defined as a complex of technological solutions in the digital space of the Internet based on a combination of software algorithms (computer codes), computer technological equipment, "cloud technologies", large databases, as well as other digital technologies [6]. It is also rightly noted that the platform as a phenomenon, an economic phenomenon, leads to redistribution of market power, allows you to imperceptibly monopolize certain areas [7]. By creating large digital platforms and using capabilities of global electronic communications, as well as owning advanced software, digital companies are able to provide their services to millions of users around the world, dominate the relevant market, having a significant impact on a particular area of the economy. In this regard, antimonopoly and other state bodies of various countries face the problem of evaluating the activities of digital companies and online platforms created by them regarding their compliance with antimonopoly legislation. Some authors even critically note that goods and markets are being formed so rapidly that antimonopoly authorities around the world do not have time not only to react promptly, but also to study them sufficiently [8]. In any case, when applying antimonopoly regulations, it is necessary to analyze the relevant digital markets, develop certain approaches to assessing the company's market power in them, as well as analyze and generalize similar experience of antimonopoly regulation in other countries.

To date, the practice of applying antimonopoly legislation in relation to digital companies continues to be actively formed and developed. At one time, the United States was one of the first to face the need to assess the compliance of the market behavior of a large high-tech company with the norms of antimonopoly legislation. In 1998, the US Department of Justice, the Attorneys General of several states and the District of Columbia filed a lawsuit against Microsoft for illegally obstructing competition in order to protect and expand its monopoly on software. The company was accused of violating articles 1 and 2 of the Sherman Act, expressed in concluding illegal exclusive agreements in the operating system market, illegal binding of the Internet Explorer browser to the Windows 95 and Windows 98 operating systems, illegal monopoly in the market of operating systems for personal computers and illegal attempt to monopolize the Internet browser market. Being the creator of the Internet Explorer browser, Microsoft pursued an extremely aggressive policy to promote its product. The browser began to be delivered free of charge along with the Windows operating system, agreements were concluded with major Internet service providers that they would include Internet Explorer in their services, support and advertise it. Also, as the suitors stated, these agreements contained conditions restricting the promotion of competing software products by Internet service providers. In addition, serious claims of the Ministry of Justice were caused by licensing agreements concluded by Microsoft with computer equipment manufacturers on the conditions for granting such entities the right to install the Windows operating system. In these agreements, Microsoft formulated a number of restrictive conditions that made it unprofitable to install a browser other than Internet Explorer on a computer. For example, manufacturing companies were forbidden to delete any 
desktop icons, folders or start menu items, change the initial boot sequence or the appearance of the desktop in the Windows operating system. At the trial, the court had to outline the market in which Microsoft operated. They defined it as the market for Intel-compatible operating systems for personal computers. The result of a lengthy trial was the withdrawal of most of the charges against Microsoft, taking into account the rule of the so-called reasonable approach. However, the company was still found guilty of dominating the operating system market and violating article 2 of the Sherman Act. Subsequently, the company concluded a settlement agreement with the suitors, the US Department of Justice included. Microsoft undertook not to restrict manufacturing companies in development, promotion or installation of any software competing with Microsoft operating systems and interfere with the distribution of products or services related to middleware, but provide competitors with certain technical information. The consequence of the measures taken by the US authorities was the development of competition in the browser market, which is currently observed by users around the world [9].

This case shows that the antimonopoly legislation of the United States, which is based on the Sherman Act of 1890 , is a fairly flexible and effective mechanism that allows counteracting manifestations of monopolistic activities in high-tech markets. The combination of antimonopoly legislation prescriptions prohibiting monopolization or attempts to monopolize any sphere of activity, and the rule of reason developed by law enforcement practice makes it possible for the law enforcement officer to take into account both public interests and interests of end consumers. At the same time, American legislation does not establish any specific quantitative criteria for market share. The latter being exceeded, the position of an economic entity will not be considered a monopoly. The issue is resolved in each specific case, taking into account the structure of the market and the position of the economic entity on it; attempts to monopolize some market segment being suppressed. In addition, the US legal doctrine fully allows the application of antitrust rules to holders of exclusive rights to the results of intellectual activity, does not grant any immunities to holders of rights to software products or other technical developments, which was once again demonstrated at the trial.

Since then, American law enforcement practice has also repeatedly faced the need to assess the market behavior of a digital company and the digital platform created by it for compliance with antitrust legislation. So, in one of the recent cases of Apple, Inc. vs Pepper, the plaintiffs - owners of Apple iPhones and buyers of mobile applications for them filed a claim for compensation for their antitrust losses as a result of the company's monopolization of the market of mobile applications for iPhones. As follows from the circumstances of the case, Apple sold mobile applications developed by various manufacturers through its App Store marketplace. The developers got an access to this platform on the following conditions. Apple forbade them to sell their applications on other trading platforms, set a commission fee of $30 \%$ on the sale of each application, and in iPhone manual required users to install only applications purchased through the App Store. As a result, the plaintiffs claimed that Apple's actions were a violation of antitrust laws and led to losses from overpayment for mobile applications, the price of which included the commission. The US Supreme Court agreed with the plaintiffs' arguments, recognized Apple's actions as unlawful and recovered damages from it in a class action. [10] This case is also notable for the fact that the American court recognized the company - operator of the digital platform responsible to consumers for the losses, despite the fact that the applications were purchased by them from other entities.

In the states of the European Union, there is also an increasing need to assess the market behavior of digital companies from the standpoint of compliance with antitrust regulations. The basis of the antimonopoly legislation of the European Union is articles 101-106 of the Treaty of 1957on the European Union functioning, which ban conclusion of anti-competitive agreements and implementation of agreed practices, as well as abuse of a dominant position by a company. In addition, the EU states have their own national regulations on the protection of competition.

A few years ago, the activities of a well-known digital platform attracted the attention of antimonopoly authorities in a number of European Union countries. It was Booking.com, which provides the possibility of booking hotels with a guarantee of the best price for the consumer. For example, in Germany, the share of this company in the booking services market is about 60 per cent. The German Antimonopoly Department (Bundeskartellamt) considered that some conditions of contracts of Booking.com with hotels limited competition, e.g. banning hotels from offering services cheaper on other online booking services, as well as displaying lower prices on their own websites. As a result, the Highest Court of the Federal Republic of Germany partially supported the position of the antimonopoly department, recognizing the ban on hotels offering cheaper accommodation options on other booking services contrary to antimonopoly legislation [9]. The antitrust proceedings conducted by the European Commission against Google were quite lengthy and multi-episode. In 2017, 2018 and 2019, the company was fined several billions of euros. Among the charges, there was the abuse of a dominant position in the market of Internet search engines by providing illegally advantages to Google Shopping's own sales service through distorting the search results of various 
products on consumer requests. The European Commission was able to prove that the offers of the main competitor of Google Shopping were issued on average on the fourth page of the search, and the offers of other competitors even further, which created unreasonable competitive advantages for the company. In addition, the company was accused of abusing its dominant position in the software market of mobile devices using the Android operating system owned by Google. Google, in contracts with manufacturers of Android-based mobile devices, in exchange for the possibility of providing licensed access to the Play Store application store, stipulated the condition of installing Google Search as the default search engine, as well as its Chrome browser, and, in some cases, made financial payments to manufacturers for Google Search and Chrome to be the only pre-installed applications in their categories.

This practice indicates rather serious violations of antimonopoly legislation on the part of digital companies, their intention to use information and technological resources available to strengthen their market position.

3. GENERAL RESULTS OF THE ANALYSIS OF THE BEHAVIOR OF DIGITAL COMPANIES IN THE MARKETS AND THEIR COMPLIANCE WITH ANTIMONOPOLY LEGISLATION

Perhaps the most extensive antitrust proceedings against digital companies in recent years has been an investigation conducted by the Subcommittee on Antitrust, Commercial and Administrative law of the House of Representatives of the US Congress, related to the assessment of the activities of companies such as Facebook, Google, Amazon and Apple. As a result of the proceedings, a large report was submitted to Congress in 2020, which contained a general conclusion that all four companies resorted to anti-competitive methods in order to strengthen their position in the market. First, Facebook has a monopoly power in the social media market. Facebook monopoly position has strengthened due to the acquisition of competing companies, in particular Instagram, and network effects, and the company actively continues to expand its influence. Second, Google has a monopoly on the markets of general Internet search and search advertising. Google's dominant position is protected by high entry barriers, including the installation of this service by default, which Google has received on most devices and browsers in the world. Google maintains its monopoly on general search through a number of anticompetitive practices, for example, in the form of misuse of third-party content and promotion of its own offers in the search engine. Google is also constantly increasing the amounts charged to companies for advertising within its platform. Third, Amazon has significant and solid market power in the US online retail market, the company has achieved its current dominant position partly by absorbing its competitors, as well as acquiring firms operating in related markets and adding data about their customers to its databases. The company uses its own information resources, as well as the position of the operator of the digital platform to gain competitive advantages when trading on the same electronic platform. Finally, Apple occupies a large share of the mobile operating system market, acting as the copyright holder of the iOS mobile operating system. The company controls the distribution of all software to iOS devices, has monopoly power in the market of mobile app stores. Apple uses its position to create and strengthen barriers to competition, discriminates and removes competitors by giving preference to its own offers. The company also sets ultra-competitive prices in the App Store [11].

Thus, in the conditions of digitalization of public relations, modern legal science and practice of antimonopoly regulation are faced with various new forms of manifestation of known violations of antimonopoly legislation, in particular monopolistic activities which have not been encountered before and the anticompetitive effect of which is becoming obvious right now. The analysis of the dynamics of modern markets allows us to conclude that the main reason for forming monopoly in the digital market space is the rapid development of goods and markets, while monopolies and a high degree of concentration of capital are the state that is inherent in the modern digital economy [12].

\section{CONCLUSION}

At the present stage of development of digitalization relations, the characteristic feature of monopolistic activities is using by companies their dominant position associated with the possession of big databases, various information technologies, including those that allow to form certain information systems, in particular digital platforms, as well as the possession of exclusive rights to the results of intellectual activities necessary to ensure the operation of these information systems and the existence of virtual markets. The study of digital companies ensuring the operation of Internet platforms allows us to conclude that such companies, acting as a strong party in relations with counterparties, may abuse their position when determining the terms of access to the digital platform in the agreement, the order of use of intellectual rights owned by the company for technical solutions or the order of use of personal data of counterparties. All this requires the antimonopoly authorities of various countries to study constantly the specifics of modern markets and improve methods of countering restrictions 
on competition from digital companies. Based on the results of this study, it seems necessary to formulate the following general conclusions:

1. The modern antimonopoly legislation of various states should be adapted to the realities of the digital economy, in particular, it should provide a methodology for the study of digital markets in order to determine the market share occupied by a particular company, criteria such as network effects, the possession of large user data, the importance of a particular resource for entrepreneurs or consumers being taken into account.

2. A digital company's intellectual property rights to certain technical developments or computer programs should not be grounds for releasing it from liability in case of committing actions prohibited by antimonopoly legislation.

3. International cooperation in the field of antimonopoly regulation could be of great benefit in countering the anti-competitive behavior of large digital monopolies, including adoption of an international act fixing the main directions, methods and recommendations to combat international digital monopolies and cartels.

\section{REFERENCES}

[1] Legal regulation of economic relations in modern conditions of digital economy development: monograph, team of authors, ed. V.A. Vaypan, M. A. Egorova, p. 25 (2019).

[2] A. Spiridonova, E. Juchnevicius, Price algorithms as a threat to competition under the conditions of digital economy: approaches to antimonopoly legislation of BRICS countries in: Brics Law Journal, 7(2) (2020) pp. 95-96. DOI: https://doi.org/10.21684/2412-2343-2020-7-2-94-

117.

[3] E. Ostanina, E. Titova, The protection of consumer rights in the digital economy conditions - the experience of the BRICS countries in: Brics Law Journal, 7(2) (2020) pp. 118-147. DOI: https://doi.org/10.21684/2412-2343-2020-7-2-118147.

[4] OECD Digital Economy Outlook 2017. OECD Publishing, Paris. 2017, pp. 206-207.

[5] Communication from the Commission to the European Parliament, the Council, the European economic and social committee and the Committee of the regions «Online Platforms and the Digital Single Market Opportunities and Challenges for Europe», May 25, 2016. https://eurlex.europa.eu/legalcontent/EN/TXT/?uri=CELEX\%3A52016DC0288.
[6] A. A. Karcahiya, Digital technological (online) platforms: Russian and foreign experience of legal regulation in: Civil law, 3 (2019) p. 25. DOI: https://doi.org/10.18572/2070-2140-2019-3-25-28.

[7] A. V. Gabov, Digital platform as a new legal phenomenon in: Perm legal almanac, 4 (2021) p. 72.

[8] D. V. SHram, Antimonopoly regulation of the activities of IT giants: the main trends in foreign and Russian legislation in: Prologue: Law Journal, 1 (2021) p. 56. DOI: https://doi.org/10.21639/23136715.2021.1.6.

[9] V. A. Avliyarova, The practice of recognizing abuse of dominant position in digital markets in the USA, Germany and Russia in: Legal view. Collection of articles of the International Scientific and Practical Conference, 160-161 (2021).

[10]Apple, Inc. v. Pepper, 587 U.S. (2019). https://supreme.justia.com/cases/federal/us/587/17$204 /$.

[11] Investigation of Competition in Digital Markets: Majority Staff Report and Recommendation. Subcommittee on antitrust, commercial and administrative law of the committee on the judiciary. United States, 2020. https:// fm.cnbc.com/applications/cnbc.com/resources/ editorialfiles/2020/10/06/investigation_of_ competition_in_digital_markets_majority_staff_ report_and_recommendations.pdf.

[12] R. SH. Kasymov, Control of monopolization in the digital economy in: Competitive law, 4 (2019) pp. 27-30. 